\title{
Budget Deficit and External Debt in Jordan: Causality and Co-Integration Analysis
}

\author{
Mohammed Issa Shahateet ${ }^{1}$, Fedel Al-Habashneh ${ }^{2} \&$ Khalid Ali Al-Majali $^{2}$ \\ ${ }^{1}$ King Talal Faculty of Business, Princess Sumaya University for Technology, Amman, Jordan \\ ${ }^{2}$ Faculty of Business Administration, Mutah University, Karak, Jordan \\ Correspondence: Mohammed Issa Shahateet, Princess Sumaya University for Technology, King Talal Faculty of \\ Business, Amman 11941, Jordan. Tel: 962-777-804-848. E-mail: msh@psut.edu.jo
}

Received: May 28, 2014

doi:10.5539/ijef.v6n8p268

\begin{abstract}
This paper examines the relationship between budget deficit and external public debt in Jordan during $1992-$ 2012. After reviewing major fiscal and monetary developments, we test for stationarity and co-integration of budget deficit and external debt. In addition, we test for the existence and direction of causality between debt and deficit. The findings of this paper provide evidence of neutrality hypotheses suggesting that there is no causality running from budget deficit to external debt and there is no causality running the other way round. Co-integration test supports the absence of long-run relationship. Empirical findings also suggest that fiscal decision makers may disregard external debt when setting budget constrains including taxes and non-interest spending. They also imply that budget constraints must rely on more important factors other than external debt when drawing fiscal policies. These factors may include good governance, tax reforms and lowering government spending on certain economic activities that have little significance on total output.
\end{abstract}

Keywords: budget deficit, external debt, causality, co-integration, Jordan

\section{Introduction}

In Jordan, as in most developing countries, economic activities of the public sector are fragmented and have little potential to enhance sustainable economic growth, yet alone carry out local proper fiscal or monetary policy. In some cases, damages caused by these policies are more than their benefits. However, as stated by Roubini and Sachs (1989), governments are not the monolithic entities of standard economic models that have full control of the policy instruments and that manage them according to stable and well-defined objectives. When power is dispersed through the alteration of political control over time, the likelihood of intertemporally inefficient budgetary policy is heightened.

Jordanian economy has been depending on foreign aid and borrowing from international creditors. At its best, the Jordanian economy is an aid-dependent economy. Several steps have been taken in order to decrease budget deficit by introducing some tax reforms and improving government collection of tax revenues. Fiscal policies have also been carried out to generate a structural change via privatization or the use of foreign aid to change the growing trend of the budget deficit.

This paper explores the relationship between the Jordanian budget deficit and external debt in order to contribute in advancing current fiscal policy and analyze public sector's vulnerability and avoid solvency problem which depends on Jordan's ability to pay external debt out of its own resources. The rest of the paper is divided into five sections. The next section reviews fiscal and monetary developments in Jordan over the past three decades, with emphasis on budget deficit and external debt. After a literature review, Section 4 introduces the methodology of the paper and defines the data sources. Section 5 specifies an econometric model for testing the relationship between budget deficit and external debt. In Section 6, we discuss empirical findings then we present our main conclusions and policy implications.

\section{Recent Fiscal and Monetary Developments}

The Jordanian government has been depending on foreign aid to finance its expenditure or to repay its foreign debt for many years. This has had a direct effect on interest rates, inflation, and the rate of economic growth. The Jordanian Ministry of Finance is responsible for formulating and monitoring fiscal policy. It is responsible for 
managing the internal and external public debt. It is also entrusted to achieving integration between fiscal and monetary policies in order to serve the national economy, in cooperation and coordination with the Central Bank of Jordan and related institutions. The tax legislation was revised in 2009 when a new Income Tax Law (No. 28) and an amended Sales Tax Law (No. 29) were approved. The revised Income Tax Law introduced many positive structural changes simplifying the tax system. The revised law includes less elements of administrative discretion than the old law, such as the value of some penalties, the estimated tax liabilities to be included in administrative assessments sent to non-filers and stop-filers, etc. Two new by-laws related to the Income Tax Law No. 28 were issued in 2010, one exempting export profit from taxes and the other related to tax court procedures, (Sahurie et al., 2011).

The budget deficit, expressed in (positive) nominal terms, has been growing on unprecedented trend. It increased from JD119 million in 2000 to JD977 million in 2005 reaching JD1,446 million in 2010 and jumped to JD2,800 million in 2012. Its ratio to GDP has also increased dramatically, from $2.2 \%$ in 2000 to $14.3 \%$ in 2005 then to $14.8 \%$ in 2010 to reach $27.3 \%$ in 2012, as depicted in Figure 1 and Figure 2. External debt also had a positive trend over the study period. In nominal terms, it has been growing from JD5,043 million in 2000 to JD5,056 million in 2005 to slightly decrease to JD4,610 million in 2010 then increased to JD4,932 in 2012. Its ratio to GDP ranged between 48\%-93\% during 2002 and 2012, as shown in Figure 1 and Figure 2.

Recent transactions of the Jordanian economy with the rest of the world resulted in a deficit in the overall balance of the balance of payments amounting to JD2,701.4 million in 2012; up from JD824.3 million in 2011, which was reflected in the drop of net foreign assets of the banking system. Moreover, the performance of current transactions with the rest of the world resulted in a deficit in the current account amounting to JD3,979.1 million (18.1percent of GDP). The capital and financial transactions resulted in a decline in net foreign assets by JD3,944.7 million. The current account registered a deficit of 18.1 percent of GDP in 2012, compared with a deficit of 12.0 percent of GDP in 2011, due to the following developments:

- An increase in the trade balance deficit by JD1,187.1 million, or 19.0 percent, to total JD7,448.8 million in 2012;

- A drop in the surplus of net current transfers by JD586.2 million to reach JD2,868.5 million. This decline was driven by the decrease in the surplus of net public current transfers (foreign grants) by JD383.8 million coupled with the decline in the surplus of net current transfers of the private sector by JD202.4 million, despite the increase in net workers' remittances, which went up by 4.5 percent, to stand at JD1,960.6 million;

- An increase in the deficit of the income account by JD86.1 million to stand at JD213.7 million; mainly due to the rise in the deficit of investment income by JD95.0 million;

- An increase in the surplus of the services account by JD342.9 million.

Consequently, the volume of current receipts amounted to JD13,483.9 million while the volume of current payments amounted to JD17,463.0 million. Accordingly, the coverage ratio of current receipts to current payments went down to stand at 77.2 percent in 2012, compared with 84.8 percent in 2011, (Central Bank of Jordan, 2013, pp. 75-77).

\section{Budget deficit-GDP ratio}

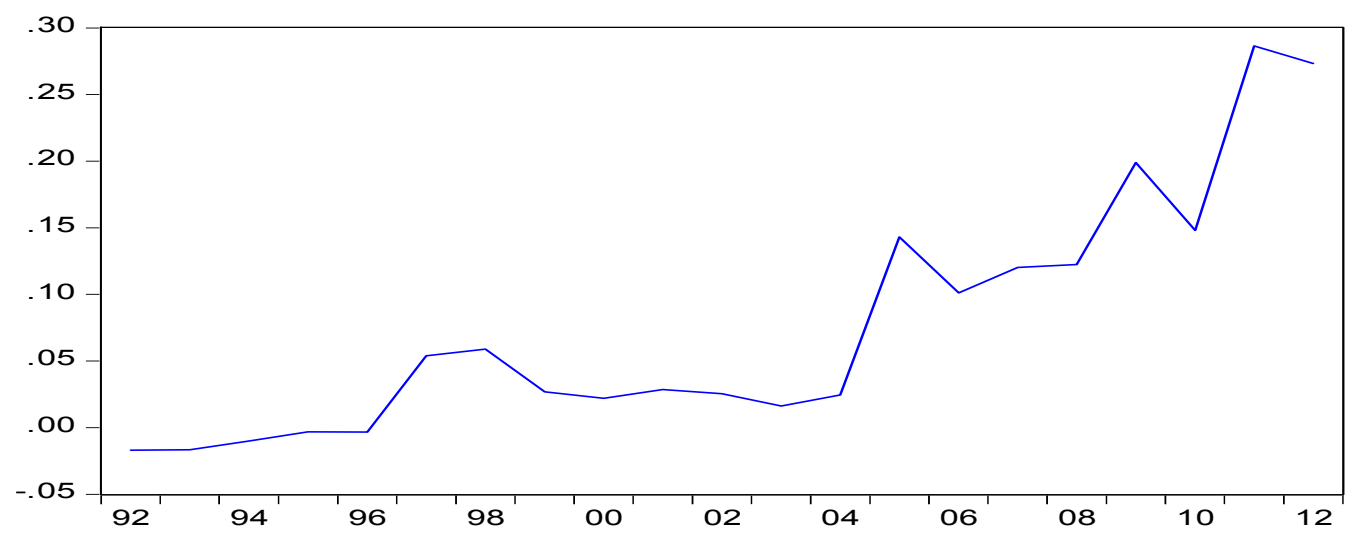

Figure 1. Growth rates of budget deficit-GDP ratio, 1992-2012 
As Figure 1 shows, the ratio of budget deficit to GDP, expressed in positive terms, was increasing over time despite the small fluctuations in 1996, 2004 and 2010, with a generally high positive trend after 2004. The ratio of external debt to GDP, expressed in negative terms and shown in Figure 2, experienced almost similar trend.

\section{External debt-GDP ratio}

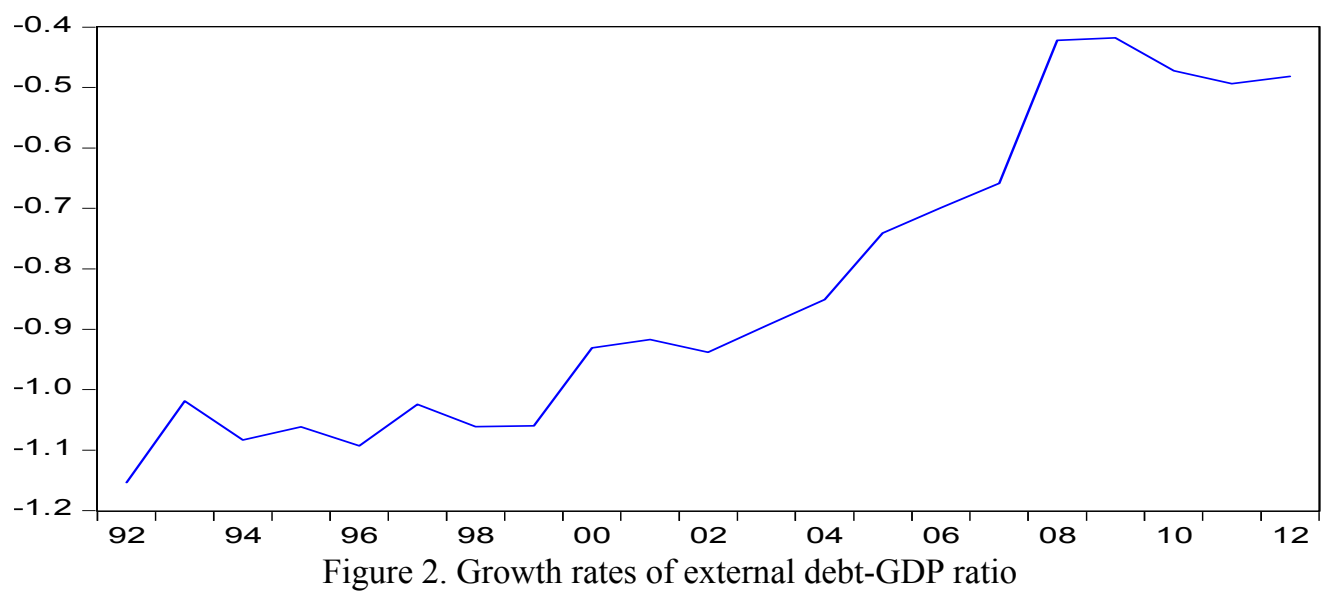

\section{Review of Literature}

Since the early 1990s, there has been an important emergence of empirical studies which explored the issue of budget deficit and external debt. These studies have gained importance after the latest financial and debt crisis world-wide. Empirical tests were carried out on stationarity and co-integration techniques that explore the existence of a long-run equilibrium relationship among the fiscal variables, (Neaime, 2004).

The effect of budget deficit or certain economic variables were also investigated recently, Agarwal (2014) for India, Chihi and Normandin (2013) for some developing countries, Bayrak and Esen (2012) and Akçay et al. (2001) in case of Turkey, Qayyum and Haider (2012) for low-income countries, Greenidge et al. (2011) in the case of Barbados and Osinubi et al. (2010) for Nigeria. Qayyum et al. (2014) also presented a theoretical model for foreign aid, external debt and governance. They showed that external debt and foreign aid do not affect the growth rate of consumption but have level impact on consumption. They concluded that foreign aid encourages the economic growth but external debt creates a burden on the economy. Foreign aid does not affect investment directly but it has a direct positive impact on the savings in the economy. Foreign aid has a positive impact on economic growth and it is playing a constructive role in spurring the economic activity of an economy. External debt has a negative impact on economic growth and it is a burden that puts an economy into trouble. They recommended that developing countries should finance budget through foreign aid and do not depend on the external debt as it affects the economic activities adversely.

Much scholarly effort that investigated the role of external debt in the economic growth has concentrated upon whether external debt has a positive or negative role in economic growth. The outcome of the research that considered LDCs either reached to a negative impact or a weak positive impact under sound policy environment or good governance. Recent studies that explored the relationship between external debt and economic growth found that external debt had a negative impact on the economy. Examining the impact of external debt on economic growth in Pakistan over the period 1970-2009, Ramzan and Ahmad (2014) showed that external debt has a negative impact on growth, but this adverse effect can be reduced or even reversed in the presence of sound macroeconomic policy. They concluded that bilateral, and not the multilateral, component of the total external debt that retards growth. Exploring the nexus between external debt and export competiveness, Ouyang and Rajan (2014) found that once external debt exceeds a certain threshold it is negatively associated with export growth. Furceri and Zdzienicka (2012) assessed the short and medium-term impact of debt crises on GDP. Using an unbalanced panel of 154 countries from 1970 to 2008, the paper shows that debt crises produce significant and long-lasting output losses, reducing output by about 10 percent after 8 years. The results also suggest that debt crises tend to be more detrimental than banking and currency crises.

On the other hand, several researchers have demonstrated the fragility of the claim, based on the sign and statistical significance of the aid-policy interaction term, that the evidence shows a positive role of LDC 
government policies in the effect of aid on growth, Ram (2004), Bianconi and Fisher (2014) for indebted open economies, Brautigam and Knack (2004) for Sub-Saharan Africa and Clements et al. (2003) for low-income countries. More recently, Hansen and Headey (2010) investigated the short-run macroeconomic impact of aid in small developing countries by using a vector auto regression (VAR) model to study the impact of aid on net import (absorption) and domestic demand (spending). They found substantial differences between 'aid-dependent' and other countries that are more dependent on natural resources, tourism or financial services. In aid-dependent countries, aid absorption more or less equals spending, although only half of the aid flow is absorbed and spent. In the non-aid-dependent group, aid does not seem to be absorbed or spent in any systematic fashion.

Empirical evidence from several studies, including Doğan and Bilgili (2014), Oguro and Sato (2014), Nasir et al. (2012), Cui and Gong (2008), Rajan and Subramanian (2007), and Easterly (2003), supports the view that aid affects growth negatively or positively only in a good policy environment. Islam (2005) found that, on average, aid had little impact on economic growth, although a robust finding is that aid promotes growth only in a politically stable environment irrespective of the quality of the country's economic policies. Aid is ineffective in an unstable environment even in the presence of good policies. The results, however, indicate that policy is more effective in promoting growth when supported by increased aid flows rather than aid being more effective in good policy environment. Collier and Dollar (2002) developed a model of efficient aid in which flows respond to policy improvements and concluded that the effect of aid depends on the quality of policies. The main implication of this entire line of research is to suggest that a good aid policy should be based upon the ability of a country to achieve poverty-reduction and implement sound policies of the kind indicated by these scholars. Burnside and Dollar (2000) claimed that aid has a positive impact on growth in developing countries with good fiscal, monetary, and trade policies.

\section{Data and Methodology}

\subsection{Data}

Modeling the relationship between budget deficit and external debt is carried out on annual data which cover the period 1992-2012. The variables of the model may be defined in nominal terms or in real terms. However, following Bohn (2007) suggestion that financial variables are better deflated by suitable scale variables like GDP or population, this paper expresses both budget deficit and external debt by their ratios to GDP. To avoid inconsistency of data, all data are taken from one Jordanian official source: The Central Bank of Jordan (1995, 2003, 2008, 2014).

\subsection{Methodology}

The methodology of this paper is of three folds. First, we investigated the existence of unit root in the variables of the model. Second, co-integration technique was used to test whether a long-run relationship exists between budget deficit and external debt. We checked for co-integration and determined the number of co-integrating equations using unrestricted co-integration rank test for both cases: Trace and Maximum Eigenvalue. Third, we applied Granger's causality test to determine the existence and direction of causality between budget deficit and external debt. The test of stationarity was carried out by applying both Augmented Dickey-Fuller (ADF) and the Phillips-Perron (PP) unit root tests including total budget deficit and total external debt, as well as the ratio of these variables to GDP. To determine the order of integration of the series, model (5) is modified to include second differences on lagged first and $k$ lags of second differences. The critical values are taken from MacKinnon-Haug-Michelis (1999) using five different assumptions about the deterministic regressors in the co-integrating equation: none, constant, linear trend, constant and linear trend, and quadratic trend. The maximum lag length is automatically selected by the estimation method based on Schwarz Information Criterion (SIC) and Akaike Information Criterion (AIC) which gave similar conclusions. Causality tests are performed using the common Granger's causality test.

\subsection{The Model}

Following Pesaran et al. (2001) and many others, we apply the following Auto Regressive Distributed Lag (ARDL) model using a constant without time trend:

$$
\begin{aligned}
& \Delta B D_{t}=\alpha_{0}+\sum_{i=1}^{n} \alpha_{1 i} \Delta B D_{t-i}+\sum_{i=0}^{m} \alpha_{2 i} \Delta E D_{t-i}+u_{1} \\
& \Delta E D_{t}=\beta_{0}+\sum_{i=1}^{n} \beta_{1 i} \Delta E D_{t-i}+\sum_{i=0}^{m} \beta_{2 i} \Delta B D_{t-i}+u_{2}
\end{aligned}
$$

We also apply the following ARDL model using a constant and linear trend: 


$$
\begin{aligned}
& \Delta B D_{t}=\gamma_{0}+\sum_{i=1}^{n} \gamma_{1 i} \Delta B D_{t-i}+\sum_{i=0}^{m} \gamma_{2 i} \Delta E D_{t-i}+\gamma_{3} t+u_{3} \\
& \Delta E D_{t}=\delta_{0}+\sum_{i=1}^{n} \delta_{1 i} \Delta E D_{t-i}+\sum_{i=0}^{m} \delta_{2 i} \Delta B D_{t-i}+\delta_{3} t+u_{4}
\end{aligned}
$$

Where $B D$ is the ratio of budget deficit to GDP, $E D$ is the ratio of external debt to GDP, and $\Delta$ is the first-difference operator. For simplicity, $n$ and $m$ represent the maximum number of lags, which is determined by the estimation method. $\alpha, \beta, \gamma$ and $\delta$ are coefficients to be estimated and $u^{\prime} s$ are stationary stochastic processes.

The application of ARDL model is based on three validations. First, ARDL model suggests that after specification of the order of the ARDL, one can estimate the level and first difference relationship between variables using ordinary least squares method. Second, the order of integration of appropriate variables may not necessarily be the same. Therefore, the ARDL technique has the advantage of not requiring a specific identification of the order of the underlying data. Third, this technique is suitable for small sample size (Pesaran et al., 2001).

\section{Results and Discussion}

We start with testing for the existence of unit root for the variables of the model. After that, we apply co-integration test to see if there are co-integrating equations and make use of the results of this test for model construction. We also apply Granger's causality test to examine the causal relationship between economic growth and energy consumption. Finally, we estimate the equations of the ARDL model under several assumptions.

\subsection{Unit Root Test}

The Augmented Dickey-Fuller (ADF) test constructs a parametric correction for higher-order correlation by assuming that the $y$ series follows an $\mathrm{AR}(k)$ process and adding $k$ lagged difference terms of the dependent variable $y$ (without more exogenous variables, in our case) to the right-hand side of the regression equation:

$$
\Delta y_{t}=\alpha+\beta y_{t-1}+\sum_{i=1}^{k} \gamma_{i} \Delta y_{t-i}+v_{t}
$$

Where $y$ is a vector of variables under study ( $B D$ and $E D$ here), $\Delta$ is first-difference operator, all small Greek letters are constant parameters to be estimated, and $v$ is white noise error term. An important result obtained by Fuller is that the asymptotic distribution of the t-ratio for $\beta$ is independent of the number of lagged first differences included in the ADF regression. For budget deficit $(B D)$, the ADF test is used in order to test the null hypothesis that the coefficient of lagged $B D$ is zero which means that there is a unit root. The alternate hypothesis is that it is less than zero, i.e., there is no unit root. More formally we want to test the null hypothesis: $H_{0}: \beta=0$, against the one-sided alternative $H_{I}: \beta<0$, based on the following formulas:

$$
\begin{gathered}
\Delta B D_{t}=\beta B D_{t-1}+\sum_{i=1}^{k} \gamma_{i} \Delta B D_{t-i}+u_{t \sigma} \\
\Delta B D_{t}=\alpha+\beta B D_{t-1}+\sum_{i=1}^{k} \gamma_{i} \Delta B D_{t-i}+u_{t 6} \\
\Delta B D_{t}=\alpha+\beta B D_{t-1}+\sum_{i=1}^{k} \gamma_{i} \Delta B D_{t-i}+\delta t+u_{t 6}
\end{gathered}
$$

For external debt $(E D)$, the ADF test is employed in order to test the null hypothesis: $H_{0}: \zeta=0$, implying that the variable $E D$ has a unit root against the one-sided alternative $H_{1}: \quad \zeta<0$, based on the following equations:

$$
\begin{gathered}
\Delta E D_{t}=\zeta E D_{t-1}+\sum_{i=1}^{m} \eta_{i} \Delta E D_{t-i}+u_{t 7} \\
\Delta E D_{t}=\varepsilon+\zeta E D_{t-1}+\sum_{i=1}^{m} \eta_{i} \Delta E D_{t-i}+u_{t 7} \\
\Delta E D_{t}=\varepsilon+\zeta E D_{t-1}+\sum_{i=1}^{m} \eta_{i} \Delta E D_{t-i}+\theta t+u_{t 7}
\end{gathered}
$$

Where $u_{t}$ is the error term which is assumed to be white noise, $k$ and $m$ are the maximum numbers of lags, and all other small Greek letters are coefficients to be estimated. The critical values are taken from MacKinnon et al. (1999) who provided response surface regression results for obtaining critical values for four different assumptions about the deterministic regressors in the co-integrating equation: none, constant, linear trend, and quadratic trend. The maximum lag length is automatically selected by the estimation method based on Schwarz Information Criterion (SIC).

The unit root tests on the budget deficit and external debt are performed including the three common options (a constant, a constant and a linear time trend, and neither) in the test regression. A unit root test for the first difference should be performed only if the variables in level have a unit root, which is the case for both $B D$ and $E D$ variables. The null hypothesis for a unit root for both budget deficit and external debt is not rejected, as 
shown in Table 1, at the 0.05 significance level. Consequently it was necessary to apply ADF test for first differences. The results of the first differenced variables show that the ADF test statistics for both budget deficit and external debt are higher than their corresponding critical values at the $5 \%$ level of significance. It should be noted that Phillips-Perron (PP) test, not presented here, was also carried out and gave conclusions similar to that of ADF test.

Table 1. Results of augmented dickey-fuller unit root test

\begin{tabular}{|c|c|c|c|c|c|}
\hline Variable & Lag length & ADF statistic & Critical value $5 \%$ & Probability & Conclusion \\
\hline \multicolumn{6}{|c|}{ None (Equations 6.1 and 7.1) } \\
\hline \multicolumn{6}{|l|}{ Budget deficit as \% GDP } \\
\hline Level & $1(4)$ & 2.307632 & -1.960171 & 0.9923 & Unit root \\
\hline First difference & $0(4)$ & -6.119835 & -1.960171 & 0.0000 & No unit root \\
\hline \multicolumn{6}{|l|}{ External debt as \% GDP } \\
\hline Level & $0(4)$ & -1.119552 & -1.959071 & 0.3570 & Unit root \\
\hline First difference & $0(4)$ & -4.262988 & -1.960171 & 0.0002 & No unit root \\
\hline \multicolumn{6}{|c|}{ Constant (Equations 6.2 and 7.2 ) } \\
\hline \multicolumn{6}{|l|}{ Budget deficit as \% GDP } \\
\hline Level & $1(4)$ & 1.175340 & -3.029970 & 0.9966 & Unit root \\
\hline First difference & $0(4)$ & -7.058259 & -3.029970 & 0.0000 & No unit root \\
\hline \multicolumn{6}{|l|}{ External debt as \% GDP } \\
\hline Level & $0(4)$ & -0.520473 & -3.020686 & 0.8676 & Unit root \\
\hline First difference & $0(4)$ & -4.768799 & -3.029970 & 0.0014 & No unit root \\
\hline \multicolumn{6}{|c|}{ Constant and linear time trend (Equations 6.3 and 7.3) } \\
\hline \multicolumn{6}{|l|}{ Budget deficit as \% GDP } \\
\hline Level & $0(4)$ & -2.413843 & -3.658446 & 0.3620 & Unit root \\
\hline First difference & $0(4)$ & -7.611239 & -3.673616 & 0.0000 & No unit root \\
\hline \multicolumn{6}{|l|}{ External debt as \% GDP } \\
\hline Level & $0(4)$ & -0.520473 & -3.020686 & 0.8676 & Unit root \\
\hline First difference & $0(4)$ & -4.752072 & -3.029970 & 0.0066 & No unit root \\
\hline
\end{tabular}

Note. The maximum lag length, shown between parentheses, is automatically selected by the estimation method based on SIC. * Probabilities and critical values calculated for 20 observations may not be accurate for small sample size.

\subsection{Co-Integration Test}

Since the unit root tests confirm that both budget deficit and external debt are non-stationary at level and stationary at first difference, then one must search for a long-run equilibrium relationship between them. The Johansen $(1991,1992)$ co-integration efficient maximum likelihood test is next used to test if they are bound by a long-run relationship. This paper applies the co-integration test to determine the number of co-integrating equations based on a modified form of model (5) to include $k$ lags of second differences. That is,

$$
\Delta^{2} y_{t}=\lambda \Delta y_{t-1}+\sum_{i=1}^{k} \mu_{i} \Delta^{2} y_{t-i}+e_{t}
$$

Using Trace method, the results of co-integration test, based on model (8), do not reject the null hypotheses of no co-integration, as shown in Table 2. The results of unrestricted co-integration rank test using Maximum Eigenvalue method, shown in Table 3, are almost similar to those of Trace method. The null hypothesis of no co-integration is not rejected, at the $5 \%$ level of significant. In fact, all results under all available co-integration testing scenarios, summarised in Table 4 and Table 5, clearly confirm that there is no long-run relationship between budget deficit and external debt for Jordan's data. As Tables 5 and 6 indicate no co-integrating vector at the 0.05 level of significance between budget deficit and external debt the null hypothesis of no co-integration cannot be rejected. Thus, fiscal policy in Jordan need not to connect budget deficit with external debt since government spending and revenues are drifting apart and do not seem to converge to a long-run equilibrium relationship. 
Table 2. Unrestricted co-integration rank test (trace)

\begin{tabular}{lccccc}
\hline \multicolumn{1}{c}{ Type of trend } & Hypothesized No. of CE(s) & Eigenvalue & Trace Statistic & 0.05 Critical Value & Prob.** \\
\hline No deterministic trend & None & 0.300282 & 7.424976 & 12.32090 & 0.2848 \\
& At most 1 & 0.033149 & 0.640505 & 4.129906 & 0.4840 \\
No deterministic trend & None & 0.373302 & 10.76156 & 20.26184 & 0.5652 \\
(restricted constant) & At most 1 & 0.094355 & 1.883046 & 9.164546 & 0.8008 \\
Linear deterministic trend & None & 0.221667 & 4.915935 & 15.49471 & 0.8177 \\
& At most 1 & 0.008100 & 0.154522 & 3.841466 & 0.6942 \\
Linear deterministic trend & None & 0.343954 & 12.76055 & 25.87211 & 0.7567 \\
(restricted) & At most 1 & 0.221264 & 4.751578 & 12.51798 & 0.6323 \\
\hline
\end{tabular}

Note. denotes rejection of the hypothesis at the 0.05 level, **MacKinnon-Haug-Michelis (1999) p-values.

Trace test indicates no co-integration at the 0.05 level.

Table 3. Unrestricted co-integration rank test (maximum eigenvalue)

\begin{tabular}{lccccc}
\hline \multicolumn{1}{c}{ Type of trend } & Hypothesized No. of CE(s) & Eigenvalue & Trace Statistic & 0.05 Critical Value & Prob.** \\
\hline No deterministic trend & None & 0.300282 & 6.784471 & 11.22480 & 0.2688 \\
& At most 1 & 0.033149 & 0.640505 & 4.129906 & 0.4840 \\
No deterministic trend & None & 0.373302 & 8.878518 & 15.89210 & 0.4470 \\
(restricted constant) & At most 1 & 0.094355 & 1.883046 & 9.164546 & 0.8008 \\
Linear deterministic trend & None & 0.221667 & 4.761412 & 14.26460 & 0.7716 \\
& At most 1 & 0.008100 & 0.154522 & 3.841466 & 0.6942 \\
Linear deterministic trend & None & 0.343954 & 8.008976 & 19.38704 & 0.8207 \\
(restricted) & At most 1 & 0.221264 & 4.751578 & 12.51798 & 0.6323 \\
\hline
\end{tabular}

Note. denotes rejection of the hypothesis at the 0.05 level, **MacKinnon-Haug-Michelis (1999) p-values.

Max-eigenvalue test indicates no co-integration at the 0.05 level.

Table 4 . Selected $(0.05$ level $)$ number of cointegrating relations by model

\begin{tabular}{cccccc}
\hline Data Trend: & None & None & Linear & Linear & Quadratic \\
\hline Test Type & No Intercept & Intercept & Intercept & Intercept & Intercept \\
& No Trend & No Trend & No Trend & Trend & Trend \\
Trace & 0 & 0 & 0 & 0 & 0 \\
Max-Eigenvalue & 0 & 0 & 0 & 0 & 0 \\
\hline
\end{tabular}

Table 5. Information criteria by rank and model

\begin{tabular}{|c|c|c|c|c|c|}
\hline Data Trend: & None & None & Linear & Linear & Quadratic \\
\hline Rank or & No Intercept & Intercept & Intercept & Intercept & Intercept \\
\hline No. of CEs & No Trend & No Trend & No Trend & Trend & Trend \\
\hline \multicolumn{6}{|c|}{ Log Likelihood by Rank (rows) and Model (columns) } \\
\hline 0 & 54.37132 & 54.37132 & 57.29414 & 57.29414 & 59.32668 \\
\hline 1 & 57.76356 & 58.81058 & 59.67484 & 61.29862 & 62.93359 \\
\hline 2 & 58.08381 & 59.75210 & 59.75210 & 63.67441 & 63.67441 \\
\hline \multicolumn{6}{|c|}{ Akaike Information Criteria by Rank (rows) and Model (columns) } \\
\hline 0 & -5.302244 & -5.302244 & -5.399383 & -5.399383 & $-5.402808^{*}$ \\
\hline 1 & -5.238269 & -5.243219 & -5.228931 & -5.294592 & -5.361431 \\
\hline 2 & -4.850927 & -4.816011 & -4.816011 & -5.018359 & -5.018359 \\
\hline \multicolumn{6}{|c|}{ Schwarz Criteria by Rank (rows) and Model (columns) } \\
\hline 0 & $-5.103415^{*}$ & $-5.103415^{*}$ & -5.101139 & -5.101139 & -5.005150 \\
\hline 1 & -4.840611 & -4.795853 & -4.731858 & -4.747811 & -4.764943 \\
\hline 2 & -4.254439 & -4.120108 & -4.120108 & -4.223042 & -4.223042 \\
\hline
\end{tabular}

Note. ${ }^{*}$ Critical values based on MacKinnon-Haug-Michelis (1999). 


\subsection{Granger Causality Test}

To determine the optimal solution of model equations, the test for the direction of causality is based on the assumption that the number of lags ranges from 1 to 2 . Table 6 presents the results of testing Granger's causality that runs from budget deficit to external debt and the other way round. The results do not reject the null hypotheses of no causality. The results support the neutrality hypothesis which implies that changes in budget deficit are not caused by changes in external debt and external debt is not caused by budget deficit (both are expressed as percentages of GDP). When the two variables are expressed in their actual values (i.e. not as percentages of GDP), we obtain the same conclusion. The results of the latter are not shown here to avoid confusion in variables definitions. Therefore, any policy which aims to reduce budget deficit is expected to have a negligible effect on external debt and policies to decrease government external debt may not significantly cause budget deficit.

Table 6. Results of pairwise Granger causality test

\begin{tabular}{lcccc}
\hline Hypotheses & Observations & F-Statistic & Probability & Decision \\
\hline $\mathrm{H}_{0}: B D$ does not Granger cause $E D$ & 19 & 0.17031 & 0.8451 & No causality \\
$\mathrm{H}_{1}: E D \rightarrow B D$ & & & & \\
$\mathrm{H}_{0}: E D$ does not Granger cause $B D$ & 19 & 1.34091 & 0.2932 & No causality \\
$\mathrm{H}_{1}: B D \rightarrow E D$ & & & & \\
\hline
\end{tabular}

Note. $B D$ is budget deficit as \% of GDP and $E D$ is external debt as \% of GDP.

\section{Conclusions and Policy Implications}

After highlighting the most recent monetary and fiscal developments in Jordan, the paper used an ARDL model to study the issue of budget deficit and external debt in Jordan, during 1992-2012. This has enabled us to reach some conclusions. First, fiscal decision makers may disregard external debt when setting budget constrains including taxes and non-interest spending. Second, budget constraints must rely on more important factors other than external debt when drawing fiscal policies. These factors may include good governance, tax reforms and lowering government spending on certain economic activities that have little significance on total output. Third, external debt is not caused by budget deficit but by other factors related to economic growth and, more likely, political factors.

\section{References}

Agarwal, A. (2014). Current account deficit and fiscal deficit a case study of India. Abhinav-National Monthly Refereed Journal of Research in Commerce \& Management, 3(2), 20-26. Retrieved from http://abhinavjournal.com/journal/index.php/ISSN-2277-1166/article/view/64

Akçay, O. C., Alper, C. E., \& Özmucur, S. (2001). Budget deficit, inflation and debt sustainability: Evidence from Turkey (1970-2000). Bogazici University Institute of Social Sciences Working Paper ISS/EC, 12.

Bayrak, M., \& Esen, Ö. (2012). Effects of Budget Deficit on Current Account Balance: Analysis of Twin Deficits Hypothesis in Case of Turkey. Ekonomik Yaklasim, 23(82), 23-49. http://dx.doi.org/10.5455/ey.20001

Bianconi, M., \& Fisher, W. H. (2014). Intertemporal Budget Policies and Macroeconomic Adjustment in Indebted Open Economies. Review of International Economics, 22(1), 116-130. http://dx.doi.org/10.1111/roie.12100

Bohn, H. (2007). Are stationarity and cointegration restrictions really necessary for the intertemporal budget $\begin{array}{llll}\text { constraint? Journal of monetary } & \text { Economics, }\end{array}$ http://dx.doi.org/10.1016/j.jmoneco.2006.12.012

Brautigam, D. A., \& Knack, S. (2004). Foreign aid, institutions and governance in Sub-Saharan Africa. Economic Development and Cultural Change, 52, 255-285. http://dx.doi.org/2010.1086/380592

Burnside, C. A., \& Dollar, D. (2000). Aid, Policies and Growth. American Economic Review, 90, 847-868. http://hdl.handle.net/10161/2032

Central Bank of Jordan. (1995). Monthly Statistical Bulletin. Central Bank of Jordan, 31(11), 42-50.

Central Bank of Jordan. (2003). Monthly Statistical Bulletin. Central Bank of Jordan, 39(9), 44-51.

Central Bank of Jordan. (2008). Monthly Statistical Bulletin. Central Bank of Jordan, 44(10), 44-51. 
Central Bank of Jordan. (2013). Annual Report 2012, Central Bank of Jordan, Amman.

Central Bank of Jordan. (2014). Monthly Statistical Bulletin. Central Bank of Jordan, 50(2), 44-54.

Chihi, F., \& Normandin, M. (2013). External and budget deficits in some developing countries. Journal of International Money and Finance, 32, 77-98. http://dx.doi.org/10.1016/j.jimonfin.2012.03.002

Clements, B. J., Bhattacharya, R., \& Nguyen, T. Q. (2003). External debt, public investment, and growth in low-income countries. International Monetary Fund, No. 2003-2249.

Collier, P., \& Dollar, D. (2002). Aid allocation and poverty reduction. European Economic Review, 46(8), 14751500. http://dx.doi.org/10.1016/S0014-2921(01)00187-8

Cui, X., \& Gong, L. (2008). Foreign aid, domestic capital accumulation, and foreign borrowing. Journal of Macroeconomics, 30(3), 1269-1284. http://dx.doi.org/10.1016/j.jmacro.2007.08.002

Doğan, İ., \& Bilgili, F. (2014). The non-linear impact of high and growing government external debt on economic growth: A Markov Regime-switching approach. Economic Modelling, 39, 213-220. http://dx.doi.org/10.1016/j.econmod.2014.02.032

Easterly, W. (2003). Can foreign aid buy growth? Journal of Economic Perspectives, 17, $23-48$. http://dx.doi.org/10.3846/1611-1699.2009.10.15-30

Furceri, D., \& Zdzienicka, A. (2012). How costly are debt crises? Journal of International Money and Finance, 31(4), 726-742. http://dx.doi.org/10.1016/j.jimonfin.2012.01.012

Greenidge, K., Holder, C., \& Moore, A. (2011). Current account deficit sustainability: the case of Barbados. Applied Economics, 43(8), 973-984. http://dx.doi.org/10.1080/00036840802600095

Hansen, H., \& Headey, D. (2010). The short-run macroeconomic impact of foreign aid to small states: an agnostic time series analysis. The Journal of Development Studies, 46(5), 877-896. http://dx.doi.org/10.1080/00220381003623848

Islam, M. N. (2005). Regime changes, economic policies and the effect of aid on growth. The Journal of Development Studies, 41(8), 1467-1492. http://dx.doi.org/10.1080/00220380500187828

Johansen, S. (1991). Estimation and hypothesis testing of co-integration vectors in Gaussian Vector Auto-regressive models. Econometrica, 59, 1551-1580. http://dx.doi.org/10.2307/2938278

Johansen, S. (1992). Determination of the co-integration rank in the presence of a linear trend. Oxford Bulletin of Economics and Statistics, 54, 383-402. http://dx.doi.org/10.1111/j.1468-0084.1992.tb00008.x

MacKinnon, J. G., Haug, A. A., \& Michelis, L. (1999). Numerical distribution functions of likelihood ratio tests

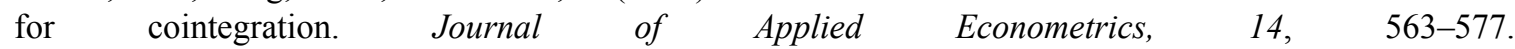
http://dx.doi.org/10.1002/(SICI)1099-1255(199909/10)14:5<563::AID-JAE530>3.0.CO;2-R

Nasir, M., Rehman, F. U., \& Orakzai, M. (2012). Exploring the nexus: Foreign aid, war on terror, and conflict in Pakistan. Economic Modelling, 29(4), 1137-1145. http://dx.doi.org/10.1016/j.econmod.2012.04.004

Neaime, S. (2004). Sustainability of budget deficits and public debt in Lebanon: a stationarity and co-integration analysis. Review of Middle East Economics and Finance, 2(1), 43-61. http://dx.doi.org/10.1080/14753680410001685678

Nickel, C., \& Vansteenkiste, I. (2008). Fiscal policies, the current account and Ricardian equivalence. European Central Bank, Working paper series No. 935.

Oguro, K., \& Sato, M. (2014). Public debt accumulation and fiscal consolidation. Applied Economics, 46(7), 663-673. http://dx.doi.org/10.1080/00036846.2013.851772

Osinubi, T. S., Dauda, R. O. S., \& Olaleru, O. E. (2010). Budget deficits, external debt and economic growth in Nigeria. The Singapore Economic Review, 55(3), 491-521. http://dx.doi.org/10.1142/S0217590810003869

Ouyang, A. Y., \& Rajan, R. S. (2014). What determines external debt tipping points? Journal of Macroeconomics, 39(Part A), 215-225. http://dx.doi.org/10.1016/j.jmacro.2013.11.001

Pesaran, M., Shin, Y., \& Smith, R. (2001). Bounds testing approaches to the analysis of level relationships. Journal of Applied Econometrics, 16, 289-326. http://dx.doi.org/10.1002/jae.616

Qayyum, U., \& Haider, A. (2012). Foreign Aid, External Debt and Economic Growth Nexus in Low-Income Countries: The Role of Institutional Quality. The Pakistan Development Review, 51(4), 97-116.

Qayyum, U., Din, M. U., \& Haider, A. (2014). Foreign aid, external debt and governance. Economic Modelling, 
37, 41-52. http://dx.doi.org/10.1016/j.econmod.2013.08.045

Rajan, R., \& Subramanian, A. (2007). Does aid affect governance? American Economic Review, 97, 322-327. http://dx.doi.org/10.1257/aer.97.2.322

Ram, R. (2004). Recipient country's policies and the effect of foreign aid on economic growth in developing countries: additional evidence. Journal of International Development, 16(2), 201-211. http://dx.doi.org/10.1002/jid.1071

Ramzan, M., \& Ahmad, E. (2014). External debt growth nexus: Role of macroeconomic policies. Economic Modelling, 38, 204-210. http://dx.doi.org/10.1016/j.econmod.2013.12.014

Roubini, N., \& Sachs, J. D. (1989). Political and economic determinants of budget deficits in the industrial democracies. European $\quad$ Economic Review, 33(5), 903-933. http://dx.doi.org/10.1016/0014-2921(89)90002-0

Sahurie, E. S., Palacio, E., Stroh, P., \& Ali, O. (2011). Jordan: repeat public financial management assessment following the PEFA methodology. ACE International Consultants, Madrid.

\section{Copyrights}

Copyright for this article is retained by the author(s), with first publication rights granted to the journal.

This is an open-access article distributed under the terms and conditions of the Creative Commons Attribution license (http://creativecommons.org/licenses/by/3.0/). 